\title{
KEMAMPUAN SISWA KELAS X SMA NEGERI 6 MEDAN MENULIS TEKS NEGOSIASI TAHUN PEMBELAJARAN 2017/2018
}

\author{
SKRIPSI \\ Diajukan Untuk Memenuhi Sebagian Syarat \\ Memperoleh Gelar Sarjana Pendidikan
}

Oleh

FAUZAH AFIFAH LUBIS

NIM 2133311036

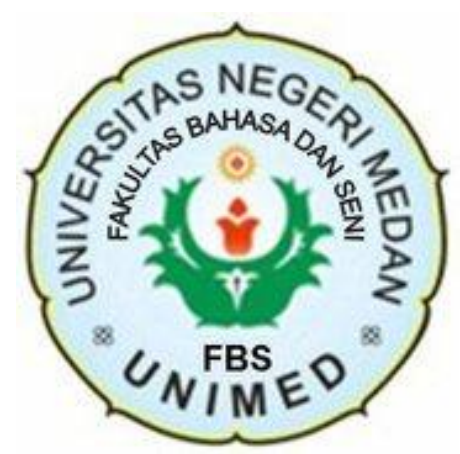

JURUSAN BAHASA DAN SASTRA INDONESIA

FAKULTAS BAHASA DAN SENI

UNIVERSITAS NEGERI MEDAN

MEDAN

2017 